\title{
Diş Hekimliğinde Kök Hücrelerin Kullanım Alanları ve Dental Kök Hücrelere İlişkin Farkındalık
}

\author{
Uses Areas of Stem Cells in Dentistry and Awareness of \\ Dental Stem Cells
}

Şule Kahraman ${ }^{1}$ (D) , Ertan Ali Delilbaşı ${ }^{2}$ (D)

\section{ÖZET}

Kök hücreler devamlı olarak yenilenebilen ve belirli hücre çeşitlerine farklılaşabilen, vücudumuzdaki doku ve organların kaynağını oluşturan ana hücrelerdir. Temel olarak embriyojenik kök hücreler ve yetişkin kök hücreler olarak ikiye ayrılırlar. Embriyojenik kök hücreler pluripotent özelliktedir. Ancak elde edilmelerinde etik problemler söz konusudur. Yetişkin kök hücreler ise sınırlı multipotent özelliktedir. Dental kök hücreler yetişkin kök hücrelerdir. Dolayısıyla elde edilmesi ve saklanmasında embriyojenik kök hücrelerdeki etik sorunlar yaşanmamaktadır. Diş hekimliğinde kök hücre çalışmaları özellikle dental kök hücre kaynaklarının kolay şekilde elde edilip, saklanabilmesi sayesinde umut veren bir alandır. Dental kök hücreler yalnızca Diş Hekimliği alanında değil, birçok tıbbi hastalıkların tedavisi için de potansiyel teşkil etmektedir. Dental kök hücreler kullanılarak tedavi sağlama süreci, dişini bağışlayacak veya saklayacak donör ve hastadan dental kök hücreleri toplayacak ve kök hücreler kullanılarak tedaviyi sağlayacak sağlayıcı, yani diş hekimi ile başlar. Diş hekimlerinin ve diş hekimliği öğrencilerinin kök hücreler ve dental kök hücrelerle ilgili belirli bilgiye sahip olmaları ve gelişmeleri takip etmeleri beklenmektedir. Bu çalışmada diş hekimliğinde kullanılan kök hücreler ve diş hekimleri ile diş hekimliği öğrencilerinin kök hücreler ve dental kök hücreler hakkında bilgi düzeylerini araştıran mevcut literatür özetlenmiştir. Bu sayede diş hekimlerinin kök hücrelere ve dental kök hücrelere dair bilgilerinin tazelenmesi ve farkındalıklarının artırııması amaçlanmaktadır.

Anahtar Kelimeler: Kök hücre; Dental kök hücre; Diş hekimliğ

\begin{abstract}
Stem cells are the basic cells that can be constantly renewed and differentiated into certain cell types, forming the source of all tissues and organs in our body. Stem cells are basically divided into embryogenic stem cells and adult stem cells. Embryogenic stem cells are pluripotent. However, there are ethical problems in their acquisition. Adult stem cells are multipotent. Dental stem cells obtained from dental tissues are adult stem cells. Stem cell studies in dentistry is promising field, especially thanks to the easy acquisition and storage of dental stem cell sources. Dental stem cells have a potential not only in the field of Dentistry, also for the treatment of many medical diseases. The process of providing treatment using dental stem cells starts with the dentist. Dentists and dental students are expected to have specific knowledge about stem cells and dental stem cells and to follow developments. In this study, the current literature investigating stem cells used in dentistry and the knowledge levels of dentists and dentistry students about stem cells and dental stem cells are summarized. In this way, it is aimed to refresh the knowledge of dentists about stem cells and dental stem cells and to increase their awareness.
\end{abstract}

Keywords: Stem cell; Dental stem cell; Dentistry

Makale gönderiliş tarihi: 3.06.2021 ; Yayına kabul tarihi: 18.10.2021

İletişim: Dr. Şule Kahraman

Emek Mah. Bişkek Cd. 1. Sokak D.No:4 Çankaya IANKARA Posta Kodu: 06490

E-posta: dtsulekahraman@gmail.com

${ }^{1}$ Dt., Gazi Üniversitesi Diş Hekimliği Fakültesi, Ağız Diş Çene Cerrahisi Ana Bilim Dalı, Çankaya, Ankara/Türkiye

2 Prof. Dr., Gazi Üniversitesi Diş Hekimliği Fakültesi, Ağız Diş Çene Cerrahisi Ana Bilim Dalı, Çankaya, Ankara/Türkiye

Bu derleme YÖK 100/2000 Doktora Burs Programı Kök Hücre Çalışmaları alanında çalışmakta olan bursiyeri tarafından hazırlanmıştır. 


\section{GíRiş}

Günümüzde kök hücre tedavileri, rejeneratif tıp dünyasında çeşitli tıbbi hastalıkların başarıı şekilde tedavisinde hızla büyüyen bir potansiyeldir. Orofasiyal alanda kök hücre kaynaklarının pek çok alternatifinin olması gelecekte doku mühendisliğinin klinik uygulamaları için yüksek derecede umut vermektedir. Bu çalışmanın amacı diş hekimliğinde kullanılan kök hücreleri özetlemek ve diş hekimleri ile diş hekimliği öğrencilerinin kök hücreler ve dental kök hücreler hakkında bilgi düzeylerini araştıran mevcut literatürü özetlemektir.

Kök hücreler vücudumuzdaki tüm doku ve organları meydana getiren, devamlı olarak kendini yenileme özelliği ile karakterize edilen, vücutta veya laboratuvar ortamında uygun koşullar sağlandığında çeşitli hücre tiplerine dönüşebilen farklılaşmamış ana hücrelerdir. Bu hücrelerin yaşam boyunca sınırsız bölünerek diğer hücrelerin yerini aldıkları düşünülmektedir. ${ }^{1,2}$

Kök hücreler genel olarak embriyojenik ve yetişkin kök hücreler olarak iki çeşittir. Embriyojenik kök hücreler, insan embriyosunun blastosistinden türetilir ve pluripotenttir. Embriyojenik kök hücreler bir çok farklı hücre dizisi boyunca farklılaşmaya yönlendirilebilir yani pluripotenttir ve farkı hastalıkların tedavisi için potansiyel olarak düşünülebilir; ancak embriyojenik kök hücrelerin elde edilmesi ve kullanımıyla alakalı yasal ve etik problemler söz konusudur. ${ }^{1,3,4}$

Yetişkin kök hücreler, doğum sonrası herhangi bir organdan elde edilen sınırlı farkıılaşma potansiyeline sahip, yani multipotent özellikte olan kök hücrelerdir. ${ }^{5}$ Kaynaklarına bağlı olarak yetişkin kök hücreler hematopoietik kök hücreler (HKH'ler) ve mezenkimal kök hücreler (MKH'ler) olarak ikiye ayrılır. ${ }^{6} \mathrm{HKH}$ 'ler periferal kan, kordon kanı ya da kemik iliğinden elde edilirken, MKH'ler limbal kök hücreler, karaciğer kök hücreleri, dermal kök hücreler, fetüsün mezoderm tabakasından, kemik iliği ve dental kök hücrelerden elde edilebilir. ${ }^{5}$

\section{Dental ve Orofasiyal Doku Kaynaklı MKH ve Kullanım Alanları}

\section{Illiak Krest ve Femur Kaynakıı MKH}

MKH'lerin en yaygın ve belgelenmiş izolasyon yöntemi iliak krestten kemik iliği aspiratı prosedürüdür.
Illiak krest ve femur kaynaklı MKH'ler özellikle kemik üzerindeki işlemlerde doku mühendisliği alanında yüksek potansiyele sahip olduğunu kanıtlamış olsa da hastalar için invaziv bir yöntem olması bakımından dezavantaja sahiptir. ${ }^{7}$

\section{Orofasiyal Kemik İliği Kaynaklı MKH}

Illiak krest ve femurdan başka orofasiyal kemik iliği de kıymetli bir MKH kaynağıdır, çeşitli intraoral veya ekstraoral cerrahi işlemler esnasında maksilla ya da mandibuladan her yaştaki hastadan elde edilebilmesi ile hastalar açısından nispeten daha tolere edilebilirdir. Orofasiyal kemik dışında daimi diş pulpası, dental folikül, apikal papilla, diş germi, periodontal ligament ve süt dişlerinden $\mathrm{MKH}$ izolasyonu sağlanmıştır. ${ }^{8,9}$

\section{Daimi Diş Pulpası ve Süt Dişi Kaynaklı MKH}

Daimi diş pulpası ve süt dişi kaynaklı kök hücreler dentinal pulpa kompleksini yenileme özelliklerine sahiptirler ve kemik iliği kaynaklı kök hücrelere de benzer fenotipte özellik gözterirler. ${ }^{9}$ Diş pulpası kolay elde edilmesi ve hasta tarafından tolere edilebilirliği ile oldukça popülerdir. Dental pulpa kaynaklı kök hücrelerin potansiyellerini araştırmak ve geliştirmek üzere araştırmalar yapılmaktadır. MKH'lerin farklılaşması sıklıkla, genleri fonksiyonel olarak aktive edebilen rekombinant proteinler veya gen terapisi olarak sinyal faktörlerinin kullanımını içerir. Transforming Büyüme Faktörü Beta 1 (TGF- $\beta 1$ ) gen tedavisinin dental pulpa kaynaklı MKH üzerine etkisi araştırılmış, hücre döngüsüne ve proliferasyona katkı sağladığı sonucuna ulaşılmıştır. ${ }^{10}$ Yapılan çalışmalarda süt dişi kök hücrelerinin (SHED) osteogeneze katkı sağlayarak konakçı hücredek defektlerde kemik rejenerasyonunda önemli bir destek sağladığı gözlenmiştir. Ayrıca süt dişleri pulpasının kondrositler, adipositler, osteoblastlar ve mezenkimal kök hücreler intiva ettiği belirlenmiştir. $\mathrm{Bu}$ hücre çeşitleri diş hastalıkları tedavisinin yan sıra, Alzheimer, konjenital kalp yetmezliği, kronik iskemik kalp hastalığı, Parkinson gibi bir çok sistemik hastalıkların tedavisi için potansiyel teşkil etmektedir. Bu sebeple zamanı geldiğinde çekilen ya da kendiliğinden düşen süt dişleri kök hücre tedavileri için eşsiz bir kaynak olabilir. ${ }^{9-15}$ 


\section{Dental Folikül ve Diş Germi Kaynaklı MKH}

Gömülü diş çekimlerinde sıklıkla dental folikül ve diş germi tıbbi atık olarak atılmaktadır. Halbuki diş folikülü, diş germi ve gelişim aşamasındaki dişlerin apikal papillası MKH izolasyonu için kullanılabilmektedir. Diş germinden elde edilen kök hücreler kemik iliği kaynaklı kök hücrelere göre daha yüksek osteokalsin ekspresyonu ve kalsiyum yığılımı göstermiştir. Dolayısıyla kemik rejenerasyonu için alternatif bir kök hücre kaynağı olabileceği düşünülebilir. ${ }^{16-18}$

\section{Periodontal Ligament Kaynaklı MKH}

Periodontal ligament kaynaklı MKH'lerin yapılan çaIışmalarda kemik rejenerasyonunda otojen kaynak olabileceği belirtilmiştir. Sağlıklı periodontal dokulardan elde edilen kök hücrelerle periodontal defektli bölgelerden elde edilen kök hücreler benzer özellikler göstermiştir. Bu kök hücrelerin, kemik iliği ve dental pulpa kaynaklı kök hücrelere benzer yapıda olduğu gözlenmiştir. Periodontal ligamentten köken alan öncü hücrelerin nöral krest kaynaklarından dolayı, adiposit ve nöral diferensiyasyon özelliğine sahip oldukları kanıtlanmıştır ve bunun sonucu olarak periodontal rejenerasyonun dışında hücresel tedavilerde alternatif seçenek olabilecekleri öngörülmektedir 19,20

\section{Periost Kaynaklı MKH}

Maksiller ve mandibular periost dokusundan osteoprogenitör özellikte kök hücreler izole edilmiş olup bu hücrelerin daha çok osteojenik potansiyele sahip olduğu belirlenmiştir. Periostun dış kısmındaki katman daha çok fibroblast ve elastik lifler içerirken, iç katmanlar osteoblastları, fibroblastları, osteoprogenitör hücreleri ve MKH'leri içermektedir. Otojen kemik rejenerasyonunda periost kaynaklı kök hücreler klinik olarak denenmiş ve yapılan biyopsi analizinde rutinde yapılan geleneksel otojen greftleme yöntemlerine kıyasla daha hızlı anjiyogenez ile osteoblast ve osteoklastların birikimi gözlenmiştir. Dolayısıyla implant cerrahisi ya da otojen greftleme işlemlerinde periost kaynaklı kök hücre kullanımı bu işlemler sırasındaki iyileşme potansiyelini artırmanın yanı sıra iyileşme süresini kısaltır. ${ }^{21-25}$

\section{Oral Mukoza Kaynaklı MKH}

Literatürde oral mukozadan bugüne kadar oral epitelyal ve diş eti kaynaklı olmak üzere iki çeşit MSC tespit edilmiştir. Oral epitelyal kök hücreler mukoza- ya dönüşme potansiyeline sahip olması yumuşak doku greftleme işlemleri için iyi bir alternatif olabilir. 26-29

\section{Bişhat Yağ Dokusu Kaynaklı MKH}

Niada ve ark. ${ }^{29}$ tarafından yapılan bir hayvan çalışmasında bishat yağ dokusunun kalsifiye ekstrasellüler matriks birikimiyle osteojenik potansiyele dönüşme yeteneğine sahip progenitor hücreler intiva ettiği belirlenmiştir. Bir çok maksillofasiyal cerrahi operasyonlarda otolog yağ dokusu sıklıkla kullanılmaktadır. Uygulanan yağ dokusu operasyon bölgesinde yara iyileşmesini hızlandırır ve yeni kemik oluşumunu destekler. Yapılan çalışmalar yağ dokusu kaynaklı kök hücrelerin dental pulpa kaynaklı kök hücrelere benzer özellik göstermesi ile diş hekimliğinde rejeneratif tedavilerde başarılı bir kaynak olabileceğini ortaya koymuştur. ${ }^{30-32}$

\section{Maksiller Sinüs Membranı Kaynaklı MKH}

Yapılan güncel araştırmalar maksiller sinüs membranından elde edilen osteoprogenitör hücrelerin $\mathrm{MKH}$ belirteçlerinin yüksek ekspresyonunu intiva ettiğini göstermiştir. Bu hücrelerin osteoblast, adipositler ve kondrositlere farklılaşma potansiyeline sahip olduğu yapılan çalışmalarda gösterilmiştir. Maksiller sinüs mukozasından elde edilen kök hücrelerin, mineralize kemik benzeri yapı oluşturması ve in vivo transplantasyon sonrası MKH özelliklerini koruması özellikle maksiller atrofi vakalarında kemik rejenerasyonu için gelecekteki kullanımına dair umut vermektedir. ${ }^{33,34}$

\section{Süt Dişlerinin Kök hücre Kaynağı Olarak Saklanması}

Ülkemizde 5 Temmuz 2005 tarihli Sağlık Bakanlığı Kordon Kanı Bankacılığı Yönetmeliği ile kök hücre bankaları açılmaya başlanmış olup sayıları ve faaliyetleri gün geçtikçe artmaktadır. Özellikle süt dişlerinin ileride kök hücre kaynağı olarak saklanması oldukça popülerdir. Araştırmalar dental kök hücrelerin adipositler, nöral hücreler, osteositler, kondrositler ve miyositlere farklılaşma potansiyeli taşıdığını göstermiştir. Ayrıca muhafaza edilen dental kök hücreler donör için kullanımla sınırı olmayıp diğer aile bireyleri için de kullanılabilmektedir.

Süt dişlerinden elde edilen kök hücreler 20-25 yıla kadar bankalarda saklanabilmektedir. Bu hücreler ileride organ nakli, kanser, kalp, cilt, kas, kemik ve 
kan hastalıkları, genetik ve metabolik hastalıklar, alzheimer, parkinson gibi hastalıkların tedavisinde kullanılabilirler. Süt dişini kök hücre kaynağı olarak kullanabilmek için nekroze olmaması yani canlı olması gerekmektedir. Kendiliğinden düşen süt dişleri genellikle kanama yaratmazlar ve dişin pulpası canııığını yitirmiştir. Süt dişinin henüz canlılığını yitirmemişken örneğin yeni mobilite başlamışken alınması kök hücre hasadı bakımından daha sağlıklı ve verimlidir. Alınan süt dişi özel bir solüsyon ile nakledilir. Ayrıca çekilen süt dişi ile birlikte hastadan alınan kanın da bankaya gönderilmesi gerekmektedir. Dental kök hücrelerini saklamak isteyen hastaların diş hekimleri ile temasa geçmeleri gerekli olduğundan diş hekimlerinin dental kök hücrelerin saklanması ve bankaya iletilmesi prosedürlerini biliyor olması gereklidir. Ayrıca saklamayı talep eden ailenin banka ile görüşerek saklama koşullarının maddi külfetini öğrenmesi gereklidir. Ülkemizdeki bankalar 1,5,10,15 yıllık ödeme paketleri sunmaktadır. Kök hücre bankalarındaki saklama bedeli kök hücre konusunda bilgi sahibi olup, saklama talebi olsa dahi her ailenin bunu karşılamayacağı da göz ardı edilmemesi gereken sosyolojik bir problemdir.

\section{Kök Hücre Tedavilerinde Diş Hekimlerinin Farkındalık Düzeyi}

Literatürdeki diş hekimlerinin kök hücrelere yönelik farkındalığını inceleyen araştırmalar, çeşitli ülkelerdeki diş hekimleri ve diş hekimliği öğrencileri tarafından kök hücre ve dental kök hücrelere yönelik bilgi düzeylerini ve potansiyel uygulamalarını göstermiştir. Bu alandaki çalışmalar sınırlı olup, genel olarak çeşitli sağlık meslek grupları arasında kök hücreler hakkında yetersiz bilgi olduğu bildirilmiştir.

\section{Suudi Arabistan}

Suudi Arabistan'da 14 fakülteden yeni mezun olan 606 diş hekiminin dahil edildiği bir çalışmada kök hücrelere ve diş hekimliğinde kök hücre tedavisi uygulamalarına olumlu tutumları olduğu, ancak yetersiz bilgiye sahip oldukları belirlendi. Katılımcıların çoğu (\%81,9'u) kök hücreler ve tedavi yöntemleri ile ilgili kamuyu daha fazla bilgilendirmeyi kabul ederken, yine yüksek bir oranı (\%68,3'ü) gelecekte kök hücrelerle diş tedavisi konusunda bir diş hekimliği uzmanlık dalı açılırsa bu alanda uzmanlık yapmaya istekli olduklarını belirtmişlerdir. Bununla beraber katılımcıların \%47,5'inin diş hekimliğinde kök hücre tedavilerinin uygulama alanlarıyla ilgili yeterli bilgiye ulaşamadıkları belirlenmiştir. ${ }^{35}$ Yine Suudi Arabistan'da yapılan kamu ve diş hekimlerini içeren 1494 kişinin katıldığı bir anket çalışmasında halkın dental kök hücreler konusunda yetersiz bilgiye sahip olduğu, buna rağmen gelecekte dental kök hücre bankalarına kayıtlı olmaya istekli oldukları sonucuna ulaşılmıştır. Aynı çalışmada diş hekimlerinin dental kök hücre araştırmalarına karşı orta derecede yüksek algı seviyeleri mecvut olduğu sonucuna varılmış olup, dental kök hücrelere yönelik farkındalığın sosyal medya, internet ve tanıtım araçları ile toplumdaki bilgi düzeylerinin artırılması önerilmiştir. ${ }^{36}$

\section{Nijerya}

M.A. Sede ve ark. ${ }^{37}$ tarafından Nijeryalı diş hekimliği öğrencilerinin, diş hekimliğinde kök hücre tedavisi uygulamalarının müfredeta dahil edilmesine yönelik eğilimlerini değerlendiren kesitsel bir çalışma yapılmıştır. Öğrencilerin büyük çoğunluğu lisans ve lisansüstü eğitim müfredatına kök hücre konusunun daha fazla yer alması konusunda yüksek olumlu tutumda bulunmuş olup, çalışmada kök hücre konusunda bilgi düzeylerinin artmasının, kök hücre kullanımına yönelik tutumun gelişmesine katkıda bulunacağı sonucuna ulaşılmıştır. ${ }^{37}$

\section{İtalya}

İtalya'da Frati ve ark. ${ }^{38}$ yapmış olduğu farklı branştan hekimlerin kök hücre araştırmaları üzerindeki görüşlerini araştırdığı bir çalışmada hekimlerin \%60'ının kök hücrelerle alakalı özel bir bilgiye sahip olmadığı belirlenmiştir.

\section{Hindistan}

F. Katge ve ark. ${ }^{39}$ tarafından Hintli diş hekimlerinin dental kök hücrelere yönelik bilgi ve tutumlarını değerlendirmek amacıyla 823 diş hekimini kapsayan bir araştırma yapıımıştır. Çalışmaya katılan hekimlerin \%53'ü pratisyen , \%45'i yüksek lisans derecesine $\% 1.7$ 'si ise doktora derecesine sahip diş hekimleriydi. Çalışma sonucunda genel olarak kök hücrelere dair iyi bir farkındalığa sahip oldukları, ancak dental kök hücrelere yönelik uygulamalar, kaynaklar, kullanım alanlarına yönelik bilgi düzeylerinin çoğu diş hekiminde yetersiz olduğu sonucuna ulaşılmıştır. Buna rağmen, anket sonuçlarına göre, çalışmaya 
katılan hekimlerin büyük çoğunluğunun dental kök hücrelerle ile ilgili bilgilerini güncelleme konusunda istekli oldukları belirtilmiştir. Araştırmanın sonucuna göre lisansüstü eğitim gören hekimlerin daha yüksek farkındalık derecesine sahip olduğu sonucuna ulaşılmıştır. ${ }^{39}$

\section{Amerika Birleşik Devletleri}

Amerika Birleşik Devletleri'nde yapılan bir araştırmada gelecekte diş hekimlerinin dental kök hücrelerin temel sağlayıcılarından biri olarak rol alacağını, dolayısıyla bu role tam anlamıla katılabilmelerinin dental kök hücre uygulamaları, klinik uygulamaları ve bankacılığı hakkında yeterli bilgiye sahip olmaları gerektiği sonucuna ulaşılmıştır. ${ }^{40}$

\section{SONUÇ}

Kök hücre tedavilerinin gelişebilmesi ve dental kök hücrelerin kullanımının diş hekimliği ve tıp alanında ilerleme kaydedebilmesi için diş hekimlerinin konuyla alakalı belli bir bilgiye sahip olmaları ve kök hücre uygulamalarına pozitif yaklaşımda olmaları beklenmektedir. Dental ve orofasiyal dokulardan elde edilen kök hücreler, kök hücre tedavilerinde elde edilme kolaylığı, prosedürün nispeten basit olması, düşük maliyetli oluşu, hastalar için daha kabul edilebilir olması gibi avantajlara sahiptir. Dolayısıyla diş hekimlerinin kök hücrelerin kullanım alanları ve dental kök hücrelere dair farkındalığının artırıması aynı zamanda geleceğin diş hekimleri ve akademisyenleri olacak öğrencilerin de konuya ilgilerinin artırıması ile gelecekteki araştırmalara dahil olmaları teşvik edilmelidir.

\section{REFERANSLAR}

1. Casagrande L, Mattuella LG, de Araujo FB, Eduardo J. Stem cells in dental practice: perspectives in conservative pulp therapies. J Clin Pediatr Dent 2006;31:25-7.

2. Avcu F. The Biology of stem cell. Turkiye Klinikleri J Surg Med Sci 2006;2:1-4.

3. Sedgley C, Botero T. Dental stem cells and their sources. Dent Clin North America 2012;56:549-61.

4. Pandey D, Kaur S, Kamath A. Banking Umbilical Cord Blood (UCB) Stem Cells: Awareness, Attitude and Expectations of Potential Donors from One of the Largest Potential Repository (India). PLoS One 2016;11:0155782.

5. Rai S, Kaur M, Kaur S. Applications of stem cells in interdisciplinary dentistry and beyond: An overview. Ann Med Health Sci Res 2013;3:245-54.
6. Gopal KS, Lankupalli AM. Stem cell therapy: A new hope for dentist. J Clin Diagn Res 2012;6:142-4.

7. Derubeis AR, Cancedda R. Bone marrow stromal cells (BMSCs) in bone engineering: limitations and recent advances. Ann Biomed Eng 2004;32:160-5.

8. Han J, Okada H, Takai H, Nakayama Y, Maeda T, Ogata Y. Collection and culture of alveolar bone marrow multipotent mesenchymal stromal cells from older individuals. J Cell Biochem 2009;107:1198-204.

9. Gronthos S, Mankani M, Brahim J, Robey PG, Shi S. Postnatal human dental pulp stem cells (DPSCs) in vitro and in vivo. Proc Natl Acad Sci U S A 2000;97:13625-30.

10. Salkın H, Gönen ZB, Ergen E, Bahar D, Çetin M. Effects of TGF- $\beta 1$ Overexpression on Biological Characteristics of Human Dental Pulp-derived Mesenchymal Stromal Cells. Int J Stem Cells 2019;12:170-82.

11. Miura M, Gronthos S, Zhao M, Lu B, Fisher LW, Robey PG, et al. SHED: stem cells from human exfoliated deciduous teeth. Proc Natl Acad Sci USA 2003;100:5807-12.

12. Shi S, Bartold PM, Miura M, Seo BM, Robey PG, Gronthos S. The efficacy of mesenchymal stem cells to regenerate and repair dental structures. Orthod Craniofac Res 2005;8:191-9.

13. Rai B. Stem Cells from human exfoliated deciduous teeth and SHED Bank: A Mini View. The Internet Journal of Bioengineering 2: 2007.

14. Shi S, Robey PG, Gronthos S. Comparison of human dental pulp and bone marrow stromal stem cells by CDNA microarray analysis. Bone 2001;29:532-9.

15. Sonoyama W, Liu Y, Fang D, Yamaza T, Seo BM, Zhang C, et al. Mesenchymal stem cell-mediated functional tooth regeneration in swine. PLoS One 2006;1:79.

16. Park BW, Kang EJ, Byun JH, Son MG, Kim HJ, Hah YS, et al. In vitro and in vivo osteogenesis of human mesenchymal stem cells derived from skin, bone marrow and dental follicle tissues. Differentiation 2012;83:249-59.

17. Morsczeck C, Götz W, Schierholz J, Zeilhofer F, Kühn U, Möh $C$, et al. Isolation of precursor cells (PCs) from human dental follicle of wisdom teeth. Matrix Biol 2005;24:155-65.

18. Trubiani O, Orsini G, Zini N, Di lorio D, Piccirilli M, Piattelli A, et al. Re- generative potential of human periodontal ligament derived stem cells on three-dimensional biomaterials: a morphological report. J Biomed Mater Res A 2008;87:986-93.

19. Park JC, Kim JM, Jung IH, Kim JC, Choi SH, Cho KS, et al. Isolation and characterization of human periodontal ligament (PDL) stem cells (PDLSCs) from the inflamed pdl tissue: In vitro and in vivo evaluations. J Clin Periodontol 2011;38:721-31.

20. Gronthos S, Mrozik K, Shi S, Bartold P. Ovine periodontal ligament stem cells: isolation, characterization, and differentiation potential. Calcif Tissue Int 2006;79:310-7.

21. Agata $H$, Asahina I, Yamazaki $Y$, Uchida $M$, Shinohara $Y$, 
Honda MJ, et al. Effective bone engineering with periosteumderived cells. J Dent Res 2007;86:79-83.

22. Nagata M, Hoshina $H$, Li M, Arasawa M, Uematsu K, Ogawa $S$, et al. A clinical study of alveolar bone tissue engineering with cultured autogenous periosteal cells: coordinated activation of bone formation and resorption. Bone 2012;50:1123-9.

23. Schmelzeisen $R$, Schimming $R$, Sittinger M. Making bone: implant insertion into tissue-engineered bone for maxillary sinus floor augmentation-a preliminary report. J Craniomaxillofac Surg 2003;31:34-9.

24. Izumi K, Tobita $\mathrm{T}$, Feinberg SE. Isolation of human oral keratinocyte progenitor/stem cells. J Dent Res 2007;86:341-6.

25. Jones KB, Klein OD. Oral epithelial stem cells in tissue maintenance and disease: the first steps in a long journey. Int $\mathrm{J}$ Oral Sci 2013;5:121-9.

26. Izumi K, Feinberg SE, lida A, Yoshizawa M. Intraoral grafting of an ex vivo produced oral mucosa equivalent: a preliminary report. Int J Oral Maxillofac Surg 2003;32:188-97.

27. Du L, Yang P, Ge S. Culturing and characterization of human gingival mesenchymal stem cells and their chemotactic responses to stromal cell-derived factor-1. Hua Xi Kou Qiang Yi Xue Za Zhi 2015;33:238-43.

28. Niada S, Ferreira LM, Arrigoni E, Addis A, Campagnol M, Broccaioli E, et al. Stem Cell Res Ther 2013;4:148.

29. Hung CN, Mar K, Chang HC, Chiang YL, Hu HY, Lai CC, Chu RM, Ma CM. A comparison between adipose tissue and dental pulp as sources of MSCs for tooth regeneration. Biomaterials 2011;32:6995- 7005.

30. Kulakov AA, Goldshtein DV, Grigoryan AS, Rzhaninova AA, Alekseeva IS, Arutyunyan IV, Volkov AV. Clinical study of the efficiency of combined cell transplant on the basis of multipotent mesenchymal stromal adipose tissue cells in patients with pronounced deficit of the maxillary and mandibulary bone tissue. Bull Exp Biol Med 2008;146:522-5.

31. Guo J, Weng J, Rong Q, Zhang X, Zhu S, Huang D, Li X Chen SL. Investigation of multipotent postnatal stem cells from human maxillary sinus membrane. Sci Rep 2015;5:11660.

32. Kim SW, Lee IK, Yun KI, Kim CH, Park JU. Adult stem cells derived from human maxillary sinus membrane and their osteogenic differentiation. Int $\mathrm{J}$ Oral Maxillofac Implants 2009;24:991-8.

33. Alhadlaq A, Al-Maflehi N, Alzahrani S, AlAssiri A. Assessment of knowledge and attitude toward stem cells and their implications in dentistry among recent graduates of dental schools in Saudi Arabia. Saudi Dent J 2019;1:66-75.

34. Alomar RK, Aladhyani SM, Aldossary MN, Almohaimel SA Salam M, Almutairi AF. A prospective Saudi dental stem-cell bank from the perspective of the public and dental practitioners: A cross sectional survey. J Family Med Prim Care 2020;9:864-70.

35. Sede MA, Audu O, Azodo CC. Nigerian dental students' permissive tendency to the proposed organized incorporation of stem cells application into dental curriculum: a cross-sectional study. J Oral Res Rev 2016;8:72-8.

36. Frati $P$, Gulino M, Pacchiarotti A, D'Errico S, Sicuro L, Fineschi V. A survey of Italian physicians' opinion about stem cells research: what doctors prefer and what the law requires. Biomed Res Int 2014;2014:480304.

37. Katge F, Shetty AJ, Rusawat B, Vamsi K C. Knowledge and attitude of Indian dentists regarding dental stem cells: A crosssectional descriptive survey. Indian J Dent Res 2017;28:367-74.

38. Krasner $P$, Verlander $P$. Stem cells in dentistry and medicine: the dentist's role. Dent Today 2011;30:128-135. 